\title{
Validation and reproducibility of the lung function questionnaire (LFQ) for the diagnosis of COPD in Colombia
}

Abstract

Alirio Rodrigo Bastidas Goyes ${ }^{*}$ Andrés Felipe Barragán Amado, Maria Mónica Martinez, Natalia Pinzón Villamil, Arsanios Martin Daniel

Universidad de la Sabana, Chia, Cundinamarca, Colombia

\section{English:}

Introduction: The development of clinical prediction scales and their use can reduce under-diagnosis and increase early detection of chronic obstructive pulmonary disease (COPD). The performance of clinical prediction scales in Colombia is unknown. The objective of this study is to evaluate the validity and reproducibility of the lung function questionnaire (LFQ) in Colombia.

Method: A cross-sectional study was performed, with analysis of diagnostic validity and reliability in people over 40 years of age who underwent a spirometry test. The LFQ questionnaire was applied. To assess reproducibility, the test was carried out at two time points: first at the initial consultation; and then 1 day to 1 week after the previous application. Spirometry was performed immediately after the initial questionnaire, meeting the American Thoracic Society criteria.

Results: Among the 1996 subjects included in the analysis, the average age was 65 years (SD: 11.97 years), prevalence of COPD was $21.3 \%$, the intra-class correlation coefficient between the two time points was 0.844 (95\% Cl: 0.863-0.901) $(p<0.001)$, and kappa was 0.797 for the dichotomous outcome $\leq 18$ COPD risk points $(p<0.001)$, validity analysis using the area under the receiver operating characteristic curve for the population evaluated was 0.715 (95\% Cl: $0.685-0.745)$; the dichotomous outcome of the questionnaire $\leq 18$ points was as follows: sensitivity - 91.18\% (95\% Cl: 88.0-94.3); specificity $32.41 \%$ (95\% Cl: 29.8-35.0); positive predictive value - 26.7\% (95\% Cl: $24.1-29.3)$; negative predictive value - 93.15\% (95\% Cl: 90.7-95.6); likelihood ratio (LR) +: 1.34 (95\% Cl: 1.28-1.42), LR- 0.27 (95\% Cl: 0.19-0.39); number needed to diagnose: 4; number needed to misdiagnose: $2(p<0.001)$.

Conclusion: The LFQ questionnaire has good performance for the diagnosis of COPD, especially in populations without previous respiratory symptoms or usual risk factors, optimising the use of spirometry to increase its detection.

Keywords

\section{Validarea și reproductibilitatea Lung Function Questionnaire (LFQ) pentru diagnosticul BPOC în Colombia}

Romanian:

Introducere: Dezvoltarea scalelor de predicție clinică și utilizarea lor poate reduce subdiagnosticul și crește detectarea precoce a BPOC. Nu se cunoaște valoate scalelor clinice de predictie în Colombia. Obiectivul acestui studiu este de a evalua validitatea și reproductibilitatea chestionarului de funcție pulmonară (LFQ) în Colombia.

Materiale și metodă: Analiza transversală a testului diagnostic și a confidenței la populația peste 40 de ani care se prezintă pentru o spirometrie, la care a fost aplicat LFQ. Pentru a evalua reproductibilitatea, chestionarul a fost aplicat la două momente: la consultația inițială și 1-7 zile după prima aplicare. Spirometria a fost efectuată imediat după chestionarul inițial, îndeplinind criteriile ATS. 
Rezultate: 1996 subiecți, cu vârsta medie 65 de ani (ds 11,97), cu o prevalență a BPOC de 21,3\%, coeficientul de corelație între cele două momente de 0,844 (IC95: 0,863-0,901) ( $p<0,001)$ și Kappa pentru rezultatul dihotomic mai mic sau egal cu 18 puncte de risc pentru BPOC de 0,797 ( $<<0,001)$, analiza validității prin aria de sub curba caracteristicilor operaționale pentru populația evaluată a fost de 0,715 (95\% Cl: 0,685-0,745). Sensibilitatea 91,18\% (95\% Cl: 88-94,3), specificitatea 32,41\% (95\% Cl: 29,8-35), valoarea predictivă pozitivă $26.7 \%$ (95\% Cl: 24,1-29,3), valoarea predictivă negativă 93,15\% (95\% Cl 90,7-95,6), LR+: 1,34 (95\% Cl: 1,28-1,42), LR-: 0,27 (95\% Cl: 0,19-0,39), număr necesar pentru diagnostic: 4 , număr necesar pentru nondiagnostic: $2(p<0,001)$.

Concluzii: chestionarul LFQ are rezultate bune pentru diagnosticul BPOC, mai ales la populația cu simptome respiratorii anterioare și factorii de risc obișnuiți, optimizând utilizarea spirometriei pentru a crește detecția bolii.

Cuvinte-cheie

Bronhopneumopatie obstructivă cronică • spirometrie • interviu și chestionar • validitate • reproductibilitate

\section{Introduction}

Chronic obstructive pulmonary disease (COPD) is a highly frequent condition that requires early preventive and diagnostic measures so that proper management and treatment can be implemented (1). However, despite the high prevalence of COPD, ranging from $4 \%$ to $12.16 \%$ worldwide (2-4), and the fact that the initial diagnosis of the disease can be done based on a simple clinical approach, the under-diagnosis of this condition is high and can vary from $15 \%$ to $81 \%$ in different populations (5-7), affecting the proper management of patients and increasing the economic costs of the disease (5). To address this problem, in recent years, different strategies have emerged for trying to reduce the misdiagnosis: among them are the search for cases through conventional spirometry, the use of portable spirometers, peak expiratory flow measurement (PEF), use of standardised questionnaires and a combination of them. These strategies have shown an increase in the diagnosis of COPD but with variable validity and cost-effectiveness results (8-10).

The use of targeted questionnaires remains a promising strategy, since they can be implemented in different scenarios and populations, without requiring specialised equipment or personnel to use them $(10,11)$. Among the different questionnaires currently used for the diagnosis of COPD are the Lung Function Questionnaire (LFQ), a self-administered questionnaire based on five main questions derived from the Third National Health and Nutrition Examination Survey (NHANES III) (12), and the Likert scale questionnaire, which has shown, in initial validation studies, an area under the receiver operating characteristic (ROC) curve ranging from 0.652 to 0.720 , sensitivity from $73.2 \%$ to $82.6 \%$ and specificity from $47.8 \%$ to $58.2 \%$ in a primary care population in the United States, with validation studies recommended in different populations $(13,14)$.

The early recognition of subjects with COPD through questionnaires and, in this case, through the LFQ questionnaire can optimise the use of health resources, optimise the use of spirometry and implement early management measures, such as strategies to stop smoking and exposure to other risk factors (15). On the other hand, improving the follow-up and management of underdiagnosed patients could decrease exacerbations and thus improve exercise capacity and prognosis in these patients (16). However, in our environment, the reproducibility and validity of this questionnaire for fixed airflow obstruction is unknown. This study aims to determine the diagnostic performance value of this questionnaire in our environment.

\section{Method}

A cross-sectional study was performed, with analysis of reproducibility and diagnostic validity of the use of LFQ in a population of subjects over 40 years of age who underwent a spirometry pre- and post-beta-2-agonist administration in the Pulmonary Function Laboratory of the University of La Sabana Clinic in Chia, Colombia. The period of recruitment was between January 2015 and June 2019. The data collection was carried out in two visits. During the first visit, the data obtained included identification variables, sex, height, weight, race, education level, presence of respiratory symptoms, age at onset of respiratory symptoms, history of smoking, year package index, exposure to wood smoke, passive smoking and prior history of COPD and asthma. The LFQ questionnaire was administered, and the pre- and post-beta-2-agonist spirometry was performed, measuring the forced vital capacity (FVC), forced expiratory volume in the first second (FEV1) and the FEV1/FVC ratio, as well as the percentage change of FVC and FEV1. In the second visit, which occurred $24 \mathrm{~h}$ to 15 days after the first one, the LFQ questionnaire was again completed for the analysis of reproducibility.

The LFQ questionnaire in the Spanish version consists of the following five questions: 
1. How often do you have a cough with mucus production?

2. How often do you feel noises in your chest when you breathe?

3. How often are you short of breath during a physical activity?

4. How many years have you smoked?

5. How old are you?

Each question has several response options that score from the highest to the lowest on a 1-5 Likert scale; the cutoff point for discrimination is 18 points, i.e. if a score $\leq 18$ is obtained, the greater is the risk of presenting the disease.

The inclusion criteria were as follows: age over 40 years, scheduled to perform spirometry regardless of medical indication, informed consent signature for voluntary participation in the study, native Spanish language speaker and availability of time to complete the questionnaire. Subjects whose spirometry did not meet the quality criteria according to the guidelines of the American Thoracic Association, subjects submitting incomplete questionnaires, and subjects with some type of disability or limitation for communication and/or understanding of the questionnaire or spirometry technique were excluded (mental retardation, dementia, stroke sequelae, hearing loss, deafness and blindness). To carry out the spirometry tests, the same trained and qualified personnel of the pulmonary function laboratory were used, with prior calibration of the equipment and measurement of the pulmonary function tests according to the validity characteristics and reproducibility. COPD was defined as the presence of fixed airflow obstruction as defined by the American Thoracic Society (ATS) as FEV1/FVC ratio $<0.7$ after bronchodilator administration.

Convenience sampling was performed by sequentially entering the subjects in the study. The sample size was calculated using the Epidat 4.0 programme using the diagnostic test formula, with calculation of confidence interval with unknown patient condition and taking the proportion of disease $(26.7 \%)$ in the PUMA study, where the prevalence of COPD in subjects attending medical centres in the country was evaluated $(17,18)$; the expected sensitivity value of $73.2 \%$ and expected specificity of $58.2 \%$ of the study by Hanania et al (13) were taken, with a minimum of 1129 subjects being required for a precision of $5 \%$ and a $95 \%$ confidence interval $(95 \% \mathrm{Cl})$. The sample size for the reproducibility analysis was calculated using the formula to determine the intra-class correlation coefficient (ICC). An anticipated ICC $=0.85$, precision $=5$, confidence level $=95 \%$ and two observers were required, requiring a minimum of 475 subjects. The $p$ Editions were replaced with a new subject the entrance of the study.

The data was obtained automatically through an electronic collection form, which automatically entered them into an Excel spread sheet for later verification of their values by the research group for the search for transcription and correction errors. Subsequently, the database was analysed using the statistical programme SPSS version 25 (licenced), where an initial description of the study variables was made using the measures of summary of frequencies and percentages for the qualitative and average variables, respectively, and standard deviation for the quantitative variables if their distribution was normal; or medium and interquartile range for quantitative variables with non-normal distribution. Bivariate analysis was performed between the study variables and the presence or absence of COPD using the chi-square test for qualitative variables and Student's $t$-test or Mann-Whitney $U$-test for quantitative variables according to their distribution; $2 \times 2$ tables were constructed for diagnostic test analysis and calculation of sensitivity, specificity, positive predictive value, negative predictive value, positive likelihood ratio, negative likelihood ratio with the dichotomous outcome of the questionnaire $\leq 18$ and the presence or absence of nonreversible airflow obstruction by spirometry. The construction of the ROC curve with the quantitative result of the questionnaire and the presence or absence of COPD by spirometry, the number needed to diagnose (NND) and the number needed for misdiagnosis (NNMD) were also calculated for the general population and divided by groups of respiratory symptoms, history of smoking and exposure to wood smoke. The result was considered a significant if the $p$-value was $<0.05$.

The research protocol follows the international ethical guidelines of the Declaration of Helsinki and the national ethical considerations of Resolution 8430 of 1993 and the Data Protection Law 1581 of 2012 . It was presented and approved by the research committee of the University of La Sabana and by the ethics committee of the Clinic of the University of La Sabana.

\section{Results}

A total of 1996 potentially eligible patients were admitted during the study period. A total of 397 subjects did not meet inclusion criteria, and thus, 1599 subjects were taken to the final analysis. Figure 1 shows the flowchart for inclusion of the subjects in the study. Regarding the general characteristics of the population, the average age was 65 years (SD: 11.97 years), male sex comprised $44 \%$, mixed race comprised $86 \%$ and the prevalence of COPD was $21.3 \%$. The general characteristics of the studied population and their lung function are shown in Tables 1 and 2.

\section{$L F Q$ results and COPD diagnosis}

The answers to all the questions that assess cough with expectoration, wheezing, dyspnoea, age of presentation and years of cigarette consumption had significant differences between COPD and non-COPD subjects. The running time 
Table 1. General characteristics of the population

\begin{tabular}{|c|c|c|c|c|}
\hline & Total population, $n=1599$ & Without COPD, $n=1259$ & With COPD, $n=340$ & $p$-value \\
\hline Age, in years, $n(\mathrm{SD})$ & $65.3(11.9)$ & $64(11.88)$ & $70(11.03)$ & $<0.001$ \\
\hline Male sex, $n(\%)$ & $702(49.9)$ & $518(41.1)$ & $184(54.1)$ & $<0.001$ \\
\hline \multicolumn{5}{|l|}{ Race, $n(\%)$} \\
\hline $\begin{array}{l}\text { White } \\
\text { Half-blood } \\
\text { Black } \\
\text { Other }\end{array}$ & $\begin{array}{c}196(12.2) \\
1381(86.4) \\
4(3) \\
3(1)\end{array}$ & $\begin{array}{r}153(12.1) \\
1086(86.2) \\
3(2.3) \\
2(0.2)\end{array}$ & $\begin{array}{r}43(12.5) \\
295(86.7) \\
1(0.2) \\
1(0.2)\end{array}$ & 0.354 \\
\hline \multicolumn{5}{|l|}{ Educational level, $n$ (SD) } \\
\hline $\begin{array}{l}\text { None } \\
\text { Primary } \\
\text { High school } \\
\text { Technologist } \\
\text { Technical } \\
\text { Master's degree } \\
\text { Doctorate }\end{array}$ & $\begin{array}{c}20(1.2) \\
604(37.7) \\
427(26.7) \\
12(0.77) \\
121(9.3) \\
5(0.3) \\
4(0.2)\end{array}$ & $\begin{array}{c}15(1.2) \\
425(33.7) \\
356(28.2) \\
11(0.9) \\
29(9.6) \\
2(0.1) \\
4(0.3)\end{array}$ & $\begin{array}{c}5(1.4) \\
179(52.6) \\
71(20.8) \\
1(0.2) \\
150(8.5) \\
3(0.8) \\
0(0)\end{array}$ & $<0.001$ \\
\hline Years of study, $n$ (SD) & $9.3(5.6)$ & $9.8(5.56)$ & $7.5(5.51)$ & $<0.001$ \\
\hline Respiratory symptoms, $n(\%)$ & $1360(85)$ & $1046(83)$ & $314(90)$ & $<0.001$ \\
\hline Age at onset of symptoms, $n$ (SD) & $57.3(17.21)$ & $57(16.11)$ & $57.5(20.05)$ & 0.856 \\
\hline Smoking, $n(\%)$ & $733(45)$ & $553(43)$ & $180(52)$ & 0.003 \\
\hline IPA, $n(\%)$ & $15.2(23.26)$ & $12.8(21.25)$ & $22.6(27.43)$ & $<0.001$ \\
\hline Passive smoker, $n(\%)$ & $266(16)$ & $206(16.2)$ & $60(17.6)$ & 0.982 \\
\hline Exposure to wood smoke, $n(\%)$ & $937(58)$ & $702(55.8)$ & $235(69.1)$ & $<0.001$ \\
\hline Prior diagnosis of COPD, $n(\%)$ & $409(25)$ & $246(19.5)$ & $163(47.9)$ & $<0.001$ \\
\hline Prior diagnosis of asthma, $n(\%)$ & $215(13)$ & $149(11.8))$ & $66(19.4)$ & $<0.001$ \\
\hline
\end{tabular}

IPA, index package/year.

Table 2. General lung function characteristics of the population

\begin{tabular}{|c|c|c|c|c|}
\hline & Total population, $n=1559$ & Without COPD, $n=1259$ & With COPD, $n=340$ & $p$-value \\
\hline Weight, kg, $n$ (SD) & $70.6(13.74)$ & $71.4(13.86)$ & $67.7(12.86)$ & $<0.001$ \\
\hline Height, cm, $n$ (SD) & $159.6(9.25)$ & $159.6(9.29)$ & $159.7(9.10)$ & 0.954 \\
\hline \multicolumn{5}{|l|}{ Pulmonary function, L (SD) } \\
\hline FVC reference & $3.1(0.81)$ & $3.1(0.82)$ & $3.0(0.8)$ & 0.014 \\
\hline FVC pre-B2 & $2.9(0.98)$ & $3.0(0.99)$ & $2.7(0.92)$ & $<0.001$ \\
\hline FVC pre-B2, \% predicted & $94.7(21.33)$ & $96.3(20.76)$ & $88.8(22.36)$ & $<0.001$ \\
\hline FVC post-B2 & $3.0(0.97)$ & $3.1(0.97)$ & $2.9(0.97)$ & 0.001 \\
\hline FVC post-B2, \% predicted & $98.1(21.02)$ & $98.7(20.48)$ & $95.8(22.77)$ & 0.031 \\
\hline FVC, $\%$ change & $4.2(7.97)$ & $2.9(6.75)$ & $9.1(9.98)$ & 0.001 \\
\hline FEV1 reference & $2.4(0.67)$ & $2.5(0.67)$ & $2.3(0.64)$ & $<0.001$ \\
\hline FEV1 pre-B2, best & $2.2(0.82)$ & $2.4(0.77)$ & $1.5(0.61)$ & $<0.001$ \\
\hline FEV1 pre-B2, \% predicted & $90.6(25.02)$ & $97.0(21.69)$ & $66.6(21.81)$ & $<0.001$ \\
\hline FEV1 post-B2, best & $2.3(0.82)$ & $2.5(0.78)$ & $1.7(0.64)$ & $<0.001$ \\
\hline FEV1 post-B2, \% predicted & $96.4(9.96)$ & $102.2(21.31)$ & $74.9(22.40)$ & $<0.001$ \\
\hline FEV1, \% change & $7.9(9.96)$ & $6.0(7.26)$ & $14.9(14.5)$ & $<0.001$ \\
\hline FEV/FVC reference & $78.2(4.78)$ & $78.9(3.16)$ & $75.7(7.90)$ & $<0.001$ \\
\hline FEV/FVC pre-B2\%, best & $74.6(12.79)$ & $79.4(7.83)$ & $56.7(11.73)$ & $<0.001$ \\
\hline FEV/FVC pre-B2, \% predicted & $94.9(11.45)$ & $100.7(9.17)$ & $73.7(73.66)$ & $<0.001$ \\
\hline FEV/FVC post-B2\%, best & $76.8(12.4)$ & $81.7(6.86)$ & $58.6(11.32)$ & $<0.001$ \\
\hline FEV/FVC post-B2, \% predicted & $98.0(15.41)$ & $103.7(9.01)$ & $76.5(15.37)$ & $<0.001$ \\
\hline
\end{tabular}

B2, beta-2-agonist; COPD, chronic obstructive pulmonary disease; FVC, forced vital capacity; FEV, forced expiratory volume. 
Table 3. Results of the LFQ questionnaire in the general population and in patients with and without COPD

\begin{tabular}{|c|c|c|c|c|}
\hline & $\begin{array}{l}\text { Total population, } \\
\quad n=1599\end{array}$ & $\begin{array}{l}\text { Without COPD, } \\
\quad n=1259\end{array}$ & $\begin{array}{l}\text { With COPD, } \\
\qquad n=340\end{array}$ & $p$-value \\
\hline \multicolumn{5}{|l|}{ How often do you have a cough with mucus? } \\
\hline $\begin{array}{l}\text { Never, } n \text { (SD) } \\
\text { Rarely, } n \text { (SD) } \\
\text { Sometimes, } n \text { (SD) } \\
\text { Frequently, } n \text { (SD) } \\
\text { Very often, } n \text { (SD) }\end{array}$ & $\begin{array}{l}348(21.76) \\
591(36.96) \\
351(21.95) \\
208(13) \\
101(6.3)\end{array}$ & $\begin{array}{r}298(23.6) \\
481(38.2) \\
274(21.7) \\
141(11.1) \\
65(5.16)\end{array}$ & $\begin{aligned} 50 & (14.7) \\
110 & (32.3) \\
77 & (22.64) \\
67 & (19.7) \\
36 & (10.58)\end{aligned}$ & $<0.001$ \\
\hline \multicolumn{5}{|l|}{$\begin{array}{l}\text { How often do you fee sounds in your chest (gasps, whistles or vibrations) } \\
\text { when you breathe? }\end{array}$} \\
\hline $\begin{array}{l}\text { Never, } n \text { (SD) } \\
\text { Rarely, } n \text { (SD) } \\
\text { Sometimes, } n \text { (SD) } \\
\text { Frequently, } n \text { (SD) } \\
\text { Very often, } n \text { (SD) }\end{array}$ & $\begin{array}{l}664(41.5) \\
310(19.38) \\
366(22.88) \\
169(10.56) \\
90(5.62)\end{array}$ & $\begin{array}{r}583(46.3) \\
253(20.1) \\
260(20.6) \\
111(8.81) \\
52(4.13)\end{array}$ & $\begin{aligned} 81 & (23.82) \\
57 & (16.76) \\
106 & (31.1) \\
58 & (17.05) \\
38 & (11.17)\end{aligned}$ & $<0.001$ \\
\hline \multicolumn{5}{|c|}{$\begin{array}{l}\text { How often are you short of breath during a physical activity (when climbing } \\
\text { stairs or climbing a slope without resting)? }\end{array}$} \\
\hline $\begin{array}{l}\text { Never, } n \text { (SD) } \\
\text { Rarely, } n \text { (SD) } \\
\text { Sometimes, } n \text { (SD) } \\
\text { Frequently, } n \text { (SD) } \\
\text { Very often, } n \text { (SD) }\end{array}$ & $\begin{array}{l}324(21.6) \\
228(14.25) \\
361(22.57) \\
378(23.63) \\
308(19.26\end{array}$ & $\begin{array}{l}272(21.6) \\
188(14.9) \\
304(24.1) \\
291(23.1) \\
203(16.2)\end{array}$ & $\begin{aligned} 52(15.29) \\
40(11.76) \\
57(17.76) \\
87(25.58) \\
104(30.5)\end{aligned}$ & $<0.001$ \\
\hline \multicolumn{5}{|l|}{ How many years have you smoked? } \\
\hline $\begin{array}{l}\text { I have never smoked, } n(\mathrm{SD}) \\
\leq 10 \text { years, } n(\mathrm{SD}) \\
11-20 \text { years, } n(\mathrm{SD}) \\
21-30 \text { years, } n(\mathrm{SD}) \\
>30 \text { years, } n(\mathrm{SD})\end{array}$ & $\begin{array}{l}872(54.5) \\
244(15.25) \\
149(9.31) \\
107(6.69) \\
227(14.19)\end{array}$ & $\begin{array}{l}710(56.39) \\
210(16.67) \\
119(9.45) \\
76(6.03) \\
144(11.43)\end{array}$ & $\begin{array}{l}162(47.6) \\
34(10) \\
30(8.82) \\
31(9.11) \\
83(24.41)\end{array}$ & $<0.001$ \\
\hline \multicolumn{5}{|l|}{ How old are you? } \\
\hline $\begin{array}{l}<40 \text { years, } n(\mathrm{SD}) \\
40-49 \text { years, } n(\mathrm{SD}) \\
50-59 \text { years, } n(\mathrm{SD}) \\
60-69 \text { years, } n(\mathrm{SD}) \\
\geq 70 \text { years, } n(\mathrm{SD})\end{array}$ & $\begin{array}{l}15(0.93) \\
197(12.32) \\
320(20.01) \\
483(30.2) \\
584(36.52)\end{array}$ & $\begin{array}{l}15(1.19) \\
176(13.97) \\
285(822.63) \\
387(30.73) \\
396(31.45)\end{array}$ & $\begin{aligned} & (0) \\
21 & (6.17) \\
35 & (10.29) \\
96 & (28.23) \\
188 & (55.29\end{aligned}$ & $<0.001$ \\
\hline Total LFQ score, $n$ (SD) & $16.2(3.52)$ & $16.8(3.34)$ & $14.1(3.35)$ & $<0.001$ \\
\hline LFQ development time, $n$ (SD) & $0.9(0.82)$ & $0.9(0.87)$ & $0.8(0.64)$ & 0.323 \\
\hline LFQ score $\leq 18, n(\mathrm{SD})$ & $1161(0.72)$ & $851(9.67)$ & $310(0.91)$ & $<0.001$ \\
\hline LFQ score $\leq 18$ without respiratory symptoms, $n$ (SD) & $100(0.41)$ & $79(0.37)$ & $21(0.80)$ & $<0.001$ \\
\hline LFQ score $\leq 18$ with respiratory symptoms, $n$ (SD) & $1061(0.78)$ & $772(0.73)$ & $289(0.92)$ & $<0.001$ \\
\hline LFQ score $\leq 18$ without smoking, $n$ (SD) & $537(0.62)$ & $401(0.56)$ & $136(0.85)$ & $<0.001$ \\
\hline LFQ score $\leq 18$ with smoking, $n$ (SD) & $624(0.85)$ & $450(0.81)$ & $174(0.96)$ & $<0.001$ \\
\hline LFQ score $\leq 18$ no exposure to wood smoke, $n$ (SD) & $445(0.67)$ & $353(0.63)$ & $92(0.87)$ & $<0.001$ \\
\hline LFQ score $\leq 18$ exposure to wood smoke, $n$ (SD) & $716(0.76)$ & $498(0.70)$ & $218(0.92)$ & $<0.001$ \\
\hline LFQ score $\leq 18$ no smoker in the house, $n$ (SD) & $838(0.75)$ & $595(0.65)$ & $243(0.91)$ & $<0.001$ \\
\hline LFQ score $\leq 18$ with smoker in the house, $n(\mathrm{SD})$ & $201(0.75)$ & $147(0.71)$ & $54(0.9)$ & 0.003 \\
\hline LFQ score $\leq 18$ no smoking or exposure to wood smoke, $n$ (SD) & $182(055)$ & $150(0.52)$ & $32(0.76)$ & 0.004 \\
\hline LFQ score $\leq 18$ with smoking and exposure to wood smoke, $n$ (SD) & $361(0.90)$ & $247(0.87)$ & $114(0.97)$ & 0.002 \\
\hline
\end{tabular}

LFQ, lung function questionnaire.

of this questionnaire was an average of 1 minute, and the dichotomous classification with a cutoff point $\leq 18$ for COPD risk discriminates with statistically significant $p(<0.05)$ in the analysed subgroups of exposure to risk factors and presence or absence of clinical symptoms. The results of the different questions and their respective answers, as well as the dichotomous score among the general population and among patients with and without COPD, are shown in Table 3.

When performing the statistical tests to find differences between the scores of the LFQ questionnaire at the two different time points, no difference was observed between the averages of the questionnaire scores. In addition, 
Pearson's and Spearman's correlation coefficients showed a very good correlation, and the assessment of the correlation and concordance through the ICC was excellent. For the dichotomous outcome, the kappa concordance coefficient was also very good; a correlation and concordance between the score and the degree of obstruction evaluated by spirometry was not found. The results of the correlation and concordance analysis between the questionnaires and spirometry are found in Table 4.

\section{Validity analysis of the LFQ questionnaire}

In the general population and the different groups analysed, the LFQ questionnaire shows high sensitivity $(>76.19 \%)$ and low specificity $(<62.91 \%)$; these values vary depending on the population evaluated. The best relationship between the number needed to diagnose (NND) and the number needed to misdiagnose (NNDM) is among subjects without exposure to smoking or wood smoke. In subjects who did not report respiratory symptoms, this relationship remains, but it is less prominent. The area under the ROC curve shows good performance in the general population, being higher in the population that did not report respiratory symptoms. The results of sensitivity, specificity, positive and negative predictive values, positive and negative likelihood ratios, accuracy and Youden's indices, the numbers needed to diagnose, the numbers needed to misdiagnose and the areas under the ROC curve are shown in Tables 5 and 6.

\section{Discussion}

This is the first study where the use of a clinical questionnaire for the diagnosis of COPD in our region has been evaluated. Taking into account the high frequency of patients with

Table 4. Results of the correlation analysis and concordance using LFQ questionnaire

\begin{tabular}{lcrlr}
\hline & $\begin{array}{c}\text { Correlation } \\
\text { coefficient }\end{array}$ & 95\% Cl & p-value \\
\hline$t$-tests for related samples & & & 0.793 \\
Pearson's correlation coefficient & 0.884 & & $<0.001$ \\
Spearman's correlation coefficient & 0.881 & & $<0.001$ \\
ICC & 0.884 & $0.863-0.901$ & $<0.001$ \\
Cronbach's alpha & 0.938 & & \\
Kappa correlation coefficient & 0.797 & & $<0.001$ \\
ICC FEV1 pre, L, vs LFQ & 0.165 & $0.117-0.212$ & $<0.001$ \\
ICC FEV1 post, L, vs LFQ & 0.158 & $0.110-0.206$ & $<0.001$ \\
ICC FEV1/FVC pre, L, vs LFQ & 0.179 & $0.131-0.226$ & $<0.001$ \\
ICC FEV1/FVC post, L, vs LFQ & 0.183 & $0.135-0.230$ & $<0.001$ \\
\hline
\end{tabular}

ICC, intra-class correlation coefficient; FEV1, forced expiratory volume in the first second; FVC, forced vital capacity. misdiagnosed COPD worldwide, it is important to evaluate potential tools easy to implement in the search for subjects with the disease. The evaluation of the LFQ questionnaire showed excellent ICC reproducibility: 0.884 (95\% Cl: $0.863-$ 0.901 ) and good validity for the recognition of patients with COPD, defined as a FEV1/FVC post-bronchodilator ratio $<0.7$. The values obtained are similar to those obtained in American populations, where the AUC was 0.718 (95\% Cl: $0.673-0.763$ ) for the sum of the total score, and in our study, we obtained a value of $0.715(95 \% \mathrm{Cl}: 0.685-0.745)$. For the cutoff point of $\leq 18$ for the diagnosis of obstruction, we found sensitivity in our population to be greater $(91.2 \%$ vs $82.6 \%)$ and lower specificity $(32.4 \%$ vs $47.8 \%)$, compared to the original validation study of Hanania et al $(13,19)$.

The prevalence of COPD (21.3\%) is higher in our study than that reported in the community, namely $14.3 \%$ in Latin America (20) and $8.9 \%$ in Colombia (21). This increase in prevalence is explained by the sampling of subjects among people who attended care centres, not among an unselected population. However, our prevalence is similar to that reported in the PUMA study $(20.6 \%)$, which was carried out at the first-level care centres in Latin America (18). This prevalence increases as the positive predictive value is known. However, the use of the questionnaire increases the possibility of detecting cases of the disease regardless of the study population; the subdiagnosis of the disease occurs both in the community and in hospitals. In our study, only $47.9 \%$ of the subjects with the disease had a previous diagnosis of COPD, showing that the recognition percentage can increase significantly with the use of this questionnaire. On the other hand, characteristics in our population regarding male sex, low educational level and history of exposure to wood smoke could also be taken into account for the early suspicion and diagnosis of the disease (22).

In the group analysis, the highest performance of AUC was found in subjects without prior evidence of respiratory symptoms, with an area of 0.798 (95\% Cl: 0.706-0.889) and where the NND $=2$ in relation to the NNDM $=3$. However, the best relationship between the NND and the NNDM is $4-14$, found in subjects in whom there is fixed obstruction to the air flow and who have not been exposed to cigarette or wood smoke. Conversely, in subjects with chronic respiratory symptoms and in whom there is a clear risk factor, the use of this questionnaire has regular performance. The use of questionnaires in search of COPD in subjects with risk factors or attending medical centres is still valuable (23) and increases the diagnosis of the disease. However, its performance may be greater as a screening tool in the general population (24). In this manner, the spirometry resource could be optimised; subjects with a negative questionnaire result would not require additional evaluations, and in those with the positive questionnaire result, the conventional spirometry evaluation 


\begin{tabular}{|c|c|c|c|c|c|c|c|c|c|c|c|c|c|}
\hline$\sum_{z}$ & N & $m$ & $\sim$ & $\sim$ & $\sim$ & $N$ & $N$ & $\sim$ & $\sim$ & $\stackrel{\nabla}{\sim}$ & $\sim$ & $m$ & $\sim$ \\
\hline z & $\sigma$ & $N$ & เ & $\checkmark$ & $\wedge$ & $\checkmark$ & ๑ & $\nabla$ & i & $\nabla$ & $\stackrel{\circ}{\circ}$ & $N$ & $\checkmark$ \\
\hline 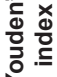 & ָָ & $\stackrel{?}{\stackrel{9}{0}}$ & $\stackrel{\infty}{\circ}$ & ঙ্ণ & $\stackrel{60}{\circ}$ & $\begin{array}{l}\stackrel{d}{0} \\
0\end{array}$ & $\begin{array}{c}\bar{N} \\
\text { O }\end{array}$ & $\stackrel{\text { N̦ }}{\circ}$ & $\stackrel{\infty}{\circ}$ & $\stackrel{\text { Nִ }}{0}$ & $\check{o}$ & $\stackrel{\text { ?}}{0}$ & ָָ \\
\hline $\begin{array}{l}0.0 \\
0 \\
\\
\end{array}$ & \begin{tabular}{l}
\multirow{5}{*}{} \\
0
\end{tabular} & & đ্ন & $\stackrel{\text { L }}{0}$ & $\begin{array}{c}\hat{m} \\
0\end{array}$ & & $\stackrel{\text { fo }}{0}$ & f̀ & ป̃ & ס̊ & 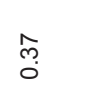 & 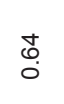 & $\begin{array}{l}\text { J } \\
0\end{array}$ \\
\hline $\begin{array}{l}\overline{0} \\
\stackrel{\circ}{\circ}\end{array}$ & $\begin{array}{l}\text { ô } \\
0 \\
0 \\
0 \\
\\
0\end{array}$ & $\begin{array}{l}\infty \\
0 \\
0 \\
0 \\
0 \\
\vdots \\
0\end{array}$ & $\begin{array}{l}\frac{\text { lo }}{0} \\
\frac{1}{N} \\
\frac{1}{0} \\
0\end{array}$ & 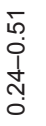 & $\begin{array}{l}9 \\
9 \\
0 \\
0 \\
0 \\
0 \\
0\end{array}$ & 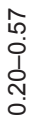 & $\begin{array}{l}9 \\
9 \\
0 \\
0 \\
0 \\
0\end{array}$ & $\begin{array}{l}\hat{m} \\
0 \\
\stackrel{1}{1} \\
\hat{0}\end{array}$ & $\begin{array}{l}\hat{N} \\
0 \\
0 \\
0 \\
0 \\
0\end{array}$ & $\begin{array}{l}\widehat{\infty} \\
0 \\
0 \\
\text { N̦ } \\
0\end{array}$ & $\begin{array}{l} \pm \\
0 \\
0 \\
8 \\
0 \\
0 \\
0\end{array}$ & $\begin{array}{l}\infty \\
0 \\
0 \\
0 \\
+ \\
0 \\
0\end{array}$ & 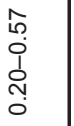 \\
\hline צّ & ָ̃ & $\stackrel{m}{\circ}$ & $\stackrel{m}{0}$ & 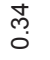 & $\stackrel{̃}{\circ}$ & 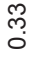 & 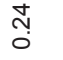 & 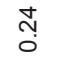 & ָे & $\stackrel{\text { ? }}{0}$ & $\stackrel{\text { N }}{0}$ & $\stackrel{m}{\circ}$ & 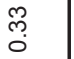 \\
\hline $\begin{array}{l}\bar{u} \\
\stackrel{\circ}{\circ}\end{array}$ & 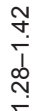 & 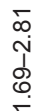 & 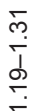 & & 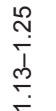 & 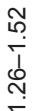 & 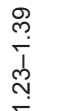 & 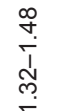 & 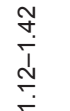 & 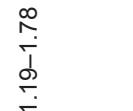 & $\begin{array}{l}\stackrel{\infty}{\leftarrow} \\
\dot{\Gamma} \\
\stackrel{\leftrightarrow}{\Gamma}\end{array}$ & 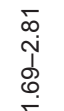 & مִ مִ \\
\hline 吕 & 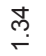 & 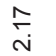 & 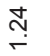 & 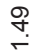 & $\stackrel{\infty}{\leftarrow}$ & 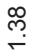 & $\stackrel{m}{\leftarrow}$ & 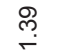 & 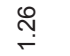 & $\stackrel{\text { Lo }}{\leftarrow}$ & 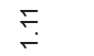 & $\stackrel{\bar{i}}{\bar{N}}$ & 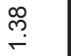 \\
\hline $\begin{array}{l}\overline{0} \\
\text { ळे }\end{array}$ & $\begin{array}{l}0 \\
\dot{\phi} \\
1 \\
1 \\
\dot{8} \\
8\end{array}$ & 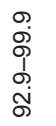 & $\begin{array}{l}\text { o } \\
\dot{d} \\
\dot{0} \\
m \\
\infty \\
\infty \\
\infty\end{array}$ & $\begin{array}{l}\hat{\aleph} \\
\stackrel{\phi}{\phi} \\
\stackrel{\infty}{\infty} \\
\dot{\infty}\end{array}$ & $\begin{array}{l}\text { N } \\
\text { ه } \\
0 \\
\infty \\
0 \\
\infty \\
\infty\end{array}$ & 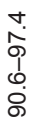 & $\begin{array}{l}- \\
\ddot{\infty} \\
0 \\
0 \\
\infty \\
\infty \\
\infty\end{array}$ & $\begin{array}{l}\circ \\
\dot{8} \\
o \\
t \\
8 \\
8\end{array}$ & $\begin{array}{l}0 \\
\infty \\
\infty \\
\infty \\
\stackrel{0}{j} \\
\infty\end{array}$ & $\begin{array}{l}0 \\
\stackrel{0}{9} \\
\infty \\
\infty \\
\infty \\
\infty\end{array}$ & $\begin{array}{l}\stackrel{8}{\stackrel{1}{1}} \\
\hat{N} \\
\infty \\
\infty\end{array}$ & 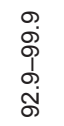 & 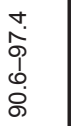 \\
\hline $\begin{array}{l}z \\
\text { n }\end{array}$ & $\frac{5}{8}$ & $\begin{array}{l}\stackrel{9}{9} \\
\stackrel{8}{8}\end{array}$ & 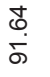 & 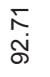 & $\begin{array}{l}\text { 号 } \\
\text { fं }\end{array}$ & $\begin{array}{l}\bar{\delta} \\
\dot{\sigma} \\
\end{array}$ & $\begin{array}{l}\bar{m} \\
\text { ભু }\end{array}$ & $\begin{array}{l}\text { న్ } \\
\text { ळై }\end{array}$ & $\begin{array}{l}\hat{\imath} \\
8\end{array}$ & $\begin{array}{l}\text { ָे } \\
\text { ळె }\end{array}$ & $\stackrel{\bar{乃}}{\stackrel{\sigma}{i}}$ & $\begin{array}{l}\stackrel{9}{q} \\
\Leftrightarrow \\
\&\end{array}$ & $\begin{array}{l}\bar{\sigma} \\
\dot{\sigma} \\
\end{array}$ \\
\hline $\begin{array}{l}\overline{0} \\
\grave{\circ}\end{array}$ & 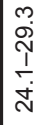 & 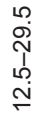 & 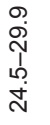 & 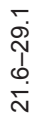 & 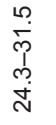 & 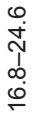 & 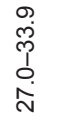 & 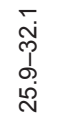 & $\begin{array}{l}N \\
\text { N } \\
0 \\
\omega \\
\tilde{D} \\
\tilde{N}\end{array}$ & 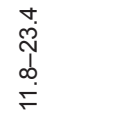 & $\begin{array}{l}0 \\
\stackrel{0}{0} \\
1 \\
1 \\
\stackrel{\infty}{N}\end{array}$ & 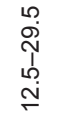 & 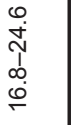 \\
\hline$\frac{a}{p}$ & 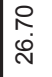 & $\frac{\stackrel{8}{+}}{\stackrel{+}{N}}$ & $\underset{\stackrel{N}{N}}{\stackrel{N}{N}}$ & 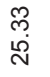 & 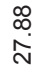 & $\begin{array}{l}\hat{\varphi} \\
\stackrel{\sim}{\grave{~}}\end{array}$ & $\begin{array}{l}\text { 吕 } \\
\text { ô }\end{array}$ & $\begin{array}{l}\stackrel{8}{.} \\
\stackrel{\text { N }}{ }\end{array}$ & $\begin{array}{l}\hat{\infty} \\
\stackrel{\infty}{N} \\
\stackrel{\infty}{n}\end{array}$ & 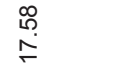 & 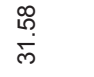 & $\underset{\stackrel{亠}{N}}{\stackrel{8}{N}}$ & $\begin{array}{l}\hat{0} \\
\stackrel{n}{\sim}\end{array}$ \\
\hline $\begin{array}{l}\bar{u} \\
\text { ڤें }\end{array}$ & $\begin{array}{l}0 \\
\infty \\
\infty \\
0 \\
\infty \\
\infty \\
\sim \\
\tilde{N}\end{array}$ & 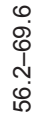 & 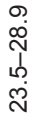 & 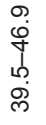 & 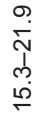 & 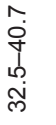 & 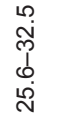 & 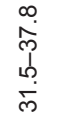 & $\begin{array}{l}0 \\
\dot{0} \\
\stackrel{1}{1} \\
\stackrel{N}{N} \\
\text { Nan }\end{array}$ & $\begin{array}{l}\hat{p} \\
0 \\
0 \\
\infty \\
\dot{\sigma} \\
\dot{y}\end{array}$ & $\begin{array}{l}\infty \\
0 \\
\stackrel{0}{1} \\
\stackrel{\infty}{\infty}\end{array}$ & $\begin{array}{l}0 \\
\stackrel{0}{0} \\
\vdots \\
\\
0 \\
0\end{array}$ & 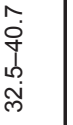 \\
\hline ш & 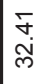 & 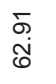 & $\begin{array}{l}\text { Nิ } \\
\text { ֻ }\end{array}$ & 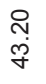 & $\begin{array}{l}0 \\
0 \\
\infty \\
\stackrel{\infty}{\infty}\end{array}$ & 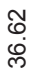 & $\begin{array}{l}\stackrel{8}{0} \\
\stackrel{\text { N }}{ }\end{array}$ & \begin{tabular}{l} 
Õ \\
\multirow{j}{*}{}
\end{tabular} & $\begin{array}{l}\mathbb{G} \\
\stackrel{0}{\infty} \\
\sim\end{array}$ & $\stackrel{+}{\stackrel{+}{\sim}}$ & 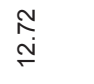 & $\begin{array}{l}\bar{S} \\
\text { đ్ర }\end{array}$ & 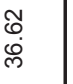 \\
\hline $\begin{array}{l}\overline{0} \\
\text { ڤั }\end{array}$ & 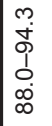 & $\begin{array}{l}\stackrel{\infty}{0} \\
\hat{1} \\
\stackrel{1}{1} \\
\dot{0}\end{array}$ & \begin{tabular}{l} 
N \\
\hdashline \\
0 \\
0 \\
$\infty$ \\
$\infty$ \\
$\infty$
\end{tabular} & 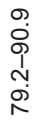 & 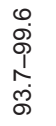 & 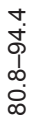 & 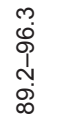 & $\begin{array}{l}9 \\
\dot{0} \\
0 \\
\infty \\
\infty \\
\stackrel{\infty}{\infty}\end{array}$ & $\begin{array}{l}+ \\
\infty \\
\infty \\
0 \\
\dot{\infty} \\
\dot{\infty}\end{array}$ & 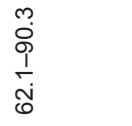 & $\begin{array}{l}\frac{8}{0} \\
\frac{1}{1} \\
\frac{c}{\dot{\sigma}}\end{array}$ & $\begin{array}{l}\stackrel{\infty}{0} \\
\hat{1} \\
\stackrel{1}{0} \\
\ddot{\theta}\end{array}$ & 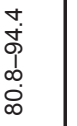 \\
\hline os & $\stackrel{\infty}{\stackrel{\infty}{\sigma}}$ & $\begin{array}{l}\hat{A} \\
\dot{\infty} \\
\text { D }\end{array}$ & 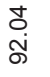 & $\begin{array}{l}\stackrel{8}{\circ} \\
\dot{\infty} \\
\infty\end{array}$ & $\begin{array}{l}\hat{6} \\
\dot{8}\end{array}$ & 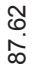 & $\begin{array}{l}\hat{N} \\
\text { N }\end{array}$ & $\begin{array}{l}\stackrel{m}{m} \\
\vdots \\
\sigma\end{array}$ & $\begin{array}{l}\text { ஃे } \\
\dot{8}\end{array}$ & 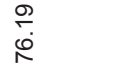 & $\begin{array}{l}\stackrel{J}{+} \\
\stackrel{\leftrightarrow}{\circ}\end{array}$ & $\begin{array}{l}\hat{\hat{O}} \\
\stackrel{\infty}{0}\end{array}$ & 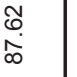 \\
\hline & 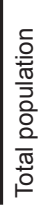 & 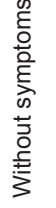 & 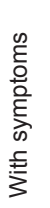 & 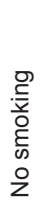 & 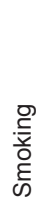 & 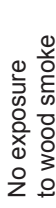 & 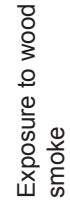 & 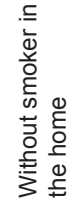 & 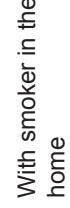 & 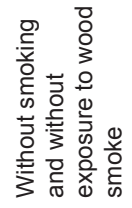 & 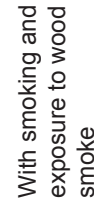 & 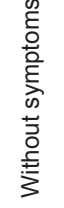 & 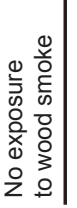 \\
\hline
\end{tabular}


Table 6. AUC of the LFQ questionnaire for COPD diagnosis

\begin{tabular}{|c|c|c|c|}
\hline & AUC & $95 \% \mathrm{Cl}$ & $p$-value \\
\hline Total population of the study & 0.715 & $0.685-0.745$ & $<0.001$ \\
\hline Population without evidence of respiratory symptoms & 0.798 & $0.706-0.889$ & $<0.001$ \\
\hline Population with respiratory symptoms & 0.694 & $0.661-0.727$ & $<0.001$ \\
\hline Population without a history of smoking & 0.713 & $0.670-0.757$ & $<0.001$ \\
\hline Population with a history of smoking & 0.706 & $0.664-0.748$ & $<0.001$ \\
\hline Population without a history of exposure to wood smoke & 0.715 & $0.661-0.770$ & $<0.001$ \\
\hline Population with a history of exposure to wood smoke & 0.705 & $0.668-0.742$ & $<0.001$ \\
\hline Population without a history of smoking at home & 0.73 & $0.697-0.763$ & $<0.001$ \\
\hline Population with a history of smoking at home & 0.653 & $0.581-0.773$ & $<0.001$ \\
\hline Population without smoking and without exposure to wood smoke & 0.671 & $0.581-0.760$ & $<0.001$ \\
\hline Population with smoking and exposure to wood smoke & 0.674 & $0.617-0.730$ & $<0.001$ \\
\hline
\end{tabular}

AUC, area under the receiver operating characteristic curve.

would be directed towards complete evaluation and thus the cost-effectiveness of spirometry in these scenarios is improved (12).

The correlation of the clinical history and respiratory symptoms to the limitation of air flow is variable. Two different observers had good agreement in determining the history of smoking with kappa of 0.95; however, it decreased with the evaluation of other clinical findings. Reproducibility for the determination of wheezing had a kappa of 0.61 , dyspnoea had kappa of 0.44-0.48 and cough showed a kappa of 0.46 (25). In this sense, the reproducibility of the LFQ questionnaire is very good, with an ICC of 0.884 for the quantitative score and 0.777 for the dichotomous outcome. The medical history remains a useful tool in the recognition of subjects with COPD or at risk for it (26); however, isolated information regarding symptoms has low sensitivity, history of cigarette consumption has sensitivity of $40 \%$, expectoration $20 \%$, wheezing $51 \%$, dyspnoea $33 \%$ and coughing $51 \%$. The use of a questionnaire that integrates the symptomatic characteristics increases the instrument's sensitivity, an important characteristic in an instrument to search for cases without increasing costs or additional resources.

Nowadays, there are questionnaires such as the CDQ (27), COPD-PS (28) and IT BE COPD, among others (29), which have also been evaluated for the diagnosis of COPD, whose performance is similar to the LFQ questionnaire; however, it is not known exactly whether one is better than the others or whether they can be used interchangeably with each other, which could still be the subject of future research. However, it seems that the use of such tools could be one of the alternatives to address the problem of misdiagnosis of the disease by focusing adequately on the use of pulmonary function tests so that a balance in cost-effectiveness is achieved in the procedures for early diagnosis of the disease (30). On the other hand, studies should be conducted on the use of additional alternatives, such as portable devices or cost-efficiency biomarkers, for easy implementation as additional alternatives that may be available in the future.

In summary, this questionnaire, which evaluates five clinical symptomatology items along with additional risk factors, has good reproducibility and validity for the detection of patients with COPD. Its validity is similar to previous validation studies in other populations, ir meets the characteristics of a screening method (high sensitivity) and it can be used in our region easily and economically. Among the possible weaknesses of the study we can consider the type of population evaluated, namely that it assesses a hospital population and thus may increase the risk of disease bias. However, patients without previous symptoms were evaluated, in whom the questionnaire showed greater capacity for discrimination, a situation similar to that found in other questionnaire validation studies, where, based on a specific score, the spirometry study is recommended for air flow confirmation.

\section{Conclusion}

The LFQ questionnaire has good reproducibility and validity for the detection of subjects with COPD, and its use can optimise the use of conventional spirometry to confirm the diagnosis of airflow obstruction.

\section{References}

1. Singh D, Agusti A, Anzueto A, Barnes PJ, Bourbeau J, Celli $B R$, et al. Global strategy for the diagnosis, management, and prevention of chronic obstructive lung disease: the GOLD science committee report 2019. The European Respiratory Journal. 2019;53(5): 1900164. 
2. Varmaghani M, Dehghani M, Heidari E, Sharifi F, Moghaddam SS, Farzadfar F. Global prevalence of chronic obstructive pulmonary disease: systematic review and meta-analysis. Eastern Mediterranean Health Journal. 2019;25(1): 47-57.

3. Halbert RJ, Isonaka S, George D, Iqbal A. Interpreting COPD prevalence estimates: what is the true burden of disease? Chest. 2003;123(5): 1684-1692.

4. Buist AS, McBurnie MA, Vollmer WM, Gillespie S, Burney P, Mannino DM, et al. International variation in the prevalence of COPD (the BOLD Study): a population-based prevalence study. Lancet (London, England). 2007;370(9589): 741-750.

5. Labonte LE, Tan WC, Li PZ, Mancino P, Aaron SD, Benedetti A, et al. Undiagnosed Chronic obstructive pulmonary disease contributes to the burden of health care use. Data from the CanCOLD Study. American Journal of Respiratory and Critical Care Medicine. 2016;194(3): 285-298.

6. Moreira GL, Manzano BM, Gazzotti MR, Nascimento OA, PerezPadilla R, Menezes AM, et al. PLATINO, a nine-year follow-up study of COPD in the city of Sao Paulo, Brazil: the problem of underdiagnosis. Jornal Brasileiro de pneumologia: Publicacao oficial da Sociedade Brasileira de Pneumologia e Tisilogia. 2014;40(1): 30-37.

7. Quach A, Giovannelli J, Cherot-Kornobis N, Ciuchete A, Clement G, Matran R, et al. Prevalence and underdiagnosis of airway obstruction among middle-aged adults in northern France: the ELISABET study 2011-2013. Respiratory Medicine. 2015;109(12): 1553-1561.

8. Buffels J, Degryse J, Heyrman J, Decramer M. Office spirometry significantly improves early detection of COPD in general practice: the DIDASCO study. Chest. 2004;125(4): 1394-1399.

9. Frith P, Crockett A, Beilby J, Marshall D, Attewell R, Ratnanesan A, et al. Simplified COPD screening: validation of the PiKo-6(R) in primary care. Primary Care Respiratory Journal. 2011;20(2): 190-198, 2 p following 8.

10. Haroon S, Jordan R, Takwoingi $Y$, Adab P. Diagnostic accuracy of screening tests for COPD: a systematic review and meta-analysis. BMJ Open. 2015;5(10): e008133.

11. Llordes M, Zurdo E, Jaen A, Vazquez I, Pastrana L, Miravitlles $M$. Which is the best screening strategy for COPD among smokers in primary care? COPD: Journal of Chronic Obstructive Pulmonary Disease. 2017;14(1): 43-51.

12. Yawn BP, Mapel DW, Mannino DM, Martinez FJ, Donohue JF, Hanania NA, et al. Development of the Lung Function Questionnaire (LFQ) to identify airflow obstruction. International Journal of Chronic Obstructive Pulmonary Disease. 2010;5: 1-10.

13. Hanania NA, Mannino DM, Yawn BP, Mapel DW, Martinez FJ, Donohue JF, et al. Predicting risk of airflow obstruction in primary care: validation of the lung function questionnaire (LFQ). Respiratory Medicine. 2010;104(8): 1160-1170.
14. Mintz ML, Yawn BP, Mannino DM, Donohue JF, Hanania NA, Grellet CA, et al. Prevalence of airway obstruction assessed by lung function questionnaire. Mayo Clinic Proceedings. 2011;86(5): 375-381.

15. Godtfredsen NS, Lam TH, Hansel TT, Leon ME, Gray N, Dresler $\mathrm{C}$, et al. COPD-related morbidity and mortality after smoking cessation: status of the evidence. The European Respiratory Journal. 2008;32(4): 844-853.

16. Vestbo J, Anderson W, Coxson HO, Crim C, Dawber F, Edwards $\mathrm{L}$, et al. Evaluation of COPD longitudinally to identify predictive surrogate end-points (ECLIPSE). The European Respiratory Journal. 2008;31(4): 869-873.

17. Lopez Varela MV, Montes de Oca M, Rey A, Casas A, Stirbulov R, Di Boscio V. Development of a simple screening tool for opportunistic COPD case finding in primary care in Latin America: the PUMA study. Respirology (Carlton, VIC). 2016;21(7): 1227-1234.

18. Schiavi E, Stirbulov R, Hernandez Vecino R, Mercurio S, Di Boscio V. COPD screening in primary care in four Latin American countries: methodology of the PUMA study. Archivos de bronconeumologia. 2014;50(11): 469-474.

19. Spyratos D, Haidich AB, Chloros D, Michalopoulou D, Sichletidis L. Comparison of three screening questionnaires for chronic obstructive pulmonary disease in the primary care. Respiration; International Review of Thoracic Diseases. 2017;93(2): 83-89.

20. Menezes AM, Perez-Padilla R, Jardim JR, Muino A, Lopez MV, Valdivia G, et al. Chronic obstructive pulmonary disease in five Latin American cities (the PLATINO study): a prevalence study. Lancet (London, England). 2005;366(9500): 1875-1881.

21. Caballero A, Torres-Duque CA, Jaramillo C, Bolivar F, Sanabria $F$, Osorio $\mathrm{P}$, et al. Prevalence of COPD in five Colombian cities situated at low, medium, and high altitude (PREPOCOL study). Chest. 2008;133(2): 343-349.

22. Nelson SB, LaVange LM, Nie Y, Walsh JW, Enright PL, Martinez FJ, et al. Questionnaires and pocket spirometers provide an alternative approach for COPD screening in the general population. Chest. 2012;142(2): 358-366.

23. Arimura Y, Yamazaki S, Shirahama T, Matsukura S, Chiyotanda $\mathrm{S}$, Nakazato M, et al. [Accuracy of COPD questionnaires in the general health check-up setting]. Nihon Kokyuki Gakkai zasshi. 2008;46(9): 693-699.

24. Murgia N, Brisman J, Claesson A, Muzi G, Olin AC, Toren K. Validity of a questionnaire-based diagnosis of chronic obstructive pulmonary disease in a general population-based study. BMC Pulmonary Medicine. 2014;14: 49.

25. Holleman DR, Jr., Simel DL, Goldberg JS. Diagnosis of obstructive airways disease from the clinical examination. Journal of General Internal Medicine. 1993;8(2): 63-68.

26. Straus SE, McAlister FA, Sackett DL, Deeks JJ. Accuracy of history, wheezing, and forced expiratory time in the diagnosis of 
chronic obstructive pulmonary disease. Journal of General Internal Medicine. 2002;17(9): 684-688.

27. Stanley AJ, Hasan I, Crockett AJ, van Schayck OC, Zwar NA. Validation of the COPD diagnostic questionnaire in an Australian general practice cohort: a cross-sectional study. Primary Care Respiratory Journal. 2014;23(1): 92-97.

28. Tsukuya G, Matsumoto K, Fukuyama S, Crawford B, Nakanishi Y, Ichinose $\mathrm{M}$, et al. Validation of a COPD screening questionnaire and establishment of diagnostic cut-points in a Japanese general population: the Hisayama study. Allergology International. 2015;64(1): 49-53.
29. Kim JK, Lee CM, Park JY, Kim JH, Park SH, Jang SH, et al. Active case finding strategy for chronic obstructive pulmonary disease with handheld spirometry. Medicine. 2016;95(50): e5683.

30. Qaseem A, Wilt TJ, Weinberger SE, Hanania NA, Criner G, van der Molen T, et al. Diagnosis and management of stable chronic obstructive pulmonary disease: a clinical practice guideline update from the American College of Physicians, American College of Chest Physicians, American Thoracic Society, and European Respiratory Society. Annals of Internal Medicine. 2011;155(3): 179-191. 